\title{
Impact of Earth's orbit and freshwater fluxes on Holocene climate mean seasonal cycle and ENSO characteristics
}

\author{
P. Braconnot • Y. Luan • Simon Brewer • \\ W. Zheng
}

Received: 20 September 2010/Accepted: 7 February 2011/Published online: 3 March 2011

(C) The Author(s) 2011. This article is published with open access at Springerlink.com

\begin{abstract}
We use a state-of-the-art 3-dimensional coupled model to investigate the relative impact of long term variations in the Holocene insolation forcing and of a freshwater release in the North Atlantic. We show that insolation has a greater effect on seasonality and La Niña events and is the major driver of sea surface temperature changes. In contrast, the variations in precipitation reflect changes in El Niño events. The impact of ice-sheet melting may have offset the impact of insolation on El Niño Southern Oscillation variability at the beginning of the Holocene. These simulations provide a coherent framework to refine the interpretation of proxy data and show that changes in seasonality may bias the projection of relationships established between proxy indicators and climate variations in the east Pacific from present day records.
\end{abstract}

Keywords Climate variability - Paleoclimate modeling . ENSO · Insolation · Fresh water fluxes · Holocene

P. Braconnot $(\varangle) \cdot$ Y. Luan · W. Zheng

Laboratoire des Sciences du climat et de l'Environnement, unité mixte CEA-CNRS-UVSQ, Orme des Merisiers,

bât. 712, 91191 Gif-sur-Yvette Cedex, France

e-mail: pascale.braconnot@1sce.ipsl.fr

Y. Luan

State Key Laboratory of Numerical Modeling for Atmospheric Sciences and Geophysical Fluid Dynamics (LASG), Institute of Atmospheric Physics (IAP),

Chinese Academy of Sciences (CAS), 100029 Beijing, China

Y. Luan

Graduate University of Chinese Academy of Sciences,

100049 Beijing, China

S. Brewer

Department of Botany, University of Wyoming,

Laramie, WY 82071, USA

\section{Introduction}

El Niño Southern Oscillation (ENSO) is one of the most prominent features of interannual variability in the tropics (Philander 1990). The associated variations in temperature, precipitation and wind have large societal and economical implications in different parts of the World, and its future evolution raises many questions (Guilyardi et al. 2009b). Past climate indicators such as coral records from the Pacific Ocean (Tudhope et al. 2001; Cobb et al. 2003) or laminated lake deposits in Ecuador (Rodbell 1999) show substantial variations in ENSO activity in the past, that have been related to insolation changes (Clement et al. 2000). Other records indicate that freshwater release from the ice-sheet melting in the Northern Atlantic induced a southward shift of the intertropical convergence zone (ITCZ) (Haug et al. 2001; Leduc et al. 2007) which also modulated past ENSO activity (Haug et al. 2001). The characteristics of tropical climate variability are shaped by several factors interacting in time, which may help explain the apparent mismatches in the reconstructions of surface temperature (Koutavas et al. 2002; Lea et al. 2000). These ambiguities need to be resolved to make appropriate use of the different proxy records in order to assess the ability of climate model to reproduce ENSO variability at different time scales.

Several studies have already shown that ENSO changes during the Holocene are tied to the long term change in the Earth's orbital parameters (e.g. Cane et al. 2006). Some of them refer to the mid or Early Holocene as a Niña-like mean state (Bush 2007), but results of the Paleoclimate Modeling Intercomparison Projet (PMIP) do not entirely support this view, even though all models produce an annual mean cooling in the Pacific (Zheng et al. 2008). These simulations of the mid-Holocene climate exhibit a 
reduced magnitude of the El Niño events (Zheng et al. 2008), which has been attributed to Bjerknes feedback (Clement et al. 2000) or to enhanced monsoon flow in autumn, counteracting the development of sea surface temperature (SST) anomalies (Liu et al. 2000; Zheng et al. 2008). The results of these simulations also suggest that the ENSO teleconnections, such as the ENSO/Sahel teleconnection were damped at that time (Otto-Bliesner 1999; Zhao et al. 2007).

However, insolation forcing is not the only driver at these time scales. A study by Timmermann et al. (2007a, b) showed ENSO characteristics could be altered in a modern climate simulation by artificially introducing a freshwater flux in the North Atlantic. Freshwater experiments on Last Glacial mean state have shown similar behaviour (Merkel et al. 2010). These conclusions need to be tested for the early to mid-Holocene, which was affected by both changes in insolation seasonality and by the continued melting of the ice-sheet and by freshwater events, e.g. the 8.2 kyear event (Clarke et al. 2004), in order to understand whether this melting may have offset some of the variations induced by orbital forcing.

Here we analyze in a common framework, the relative role of insolation and freshwater forcing, to better understand how these two forcing factors have shaped the annual mean cycle and interannual variability in the Pacific Ocean. We use a set of simulations of the Early $(9.5 \mathrm{ka})$ and MidHolocene (6 ka) with the IPSL_CM4 coupled ocean-atmosphere general circulation model (Marti et al. 2010) in which the coupling of the freshwater flux release in the ocean induced by the melting of the ice over ice-sheets is first excluded, then included. We mainly focus on the SST evolution in the Pacific Ocean. Our goal here is not to discuss in detail the underlying mechanisms, but rather to provide some guidelines to help disentangle interannual variability from seasonality in the analyses of proxy records.

The remainder of the paper is organized as follow. Section 2 presents the IPSL-CM4 coupled model and the set of early and mid-Holocene simulations. Section 3 discusses the changes in interannual variability and seasonality in response to the insolation forcing and freshwater release in the North Atlantic. The relative impact of insolation and freshwater fluxes on SST and precipitation changes is quantified in Sect. 4 , before the conclusion.

\section{Early and mid-Holocene experiments}

\subsection{The IPSL_CM4 climate model}

The IPSL_CM4 climate model is a 3-dimensional general circulation model that couples ocean, atmosphere, landsurface and sea-ice models (Marti et al. 2010). The version used here is the same as the one used for the future climate projections discussed in the last IPCC assessment report (Meehl et al. 2007). The corresponding model configuration considers a horizontal resolution of 96 points in longitude and 71 points in latitude $\left(3.7^{\circ} \times 2.5^{\circ}\right)$ for the atmosphere and 182 points in longitude and 149 points in latitude for the ocean, corresponding to a oceanic resolution of about $2^{\circ}$, with higher latitudinal resolution of $0.5^{\circ}$ in the equatorial ocean. There are 19 vertical levels in the atmosphere and 31 levels in the ocean with the highest resolution $(10 \mathrm{~m})$ in the upper $150 \mathrm{~m}$. The ocean and atmosphere exchange momentum, heat and freshwater fluxes, surface temperature and sea-ice cover once a day. The freshwater budget is closed thanks to a river runoff scheme that routes the runoff from land to the ocean.

In addition the model includes a parametrisation of landice melting through iceberg or direct runoff. This crude parameterization was first implemented for future climate projections (Swingedouw et al. 2006) and recently used to investigate the impact of icesheet melting on different climate states (Swingedouw et al. 2009). It is based on thermodynamic laws. When the glacial surface is snow free and the surface temperature is greater than $0^{\circ} \mathrm{C}$, the surface temperature is set to $0^{\circ} \mathrm{C}$ and the corresponding heat flux is used to melt the land ice. The dynamics of the ice-sheet are not considered. The land-ice areas and altitude remain fixed to their modern observed values and refreezing processes are neglected. The melt water is routed to the ocean as a freshwater flux with a 10-year average. It is not directly distributed along the ice sheet, but uniformly over a wider region, so as to mimic the iceberg transport. The Earth is divided into three latitude bands with limits at $90^{\circ} \mathrm{S} / 50^{\circ} \mathrm{S} / 40^{\circ} \mathrm{N} / 90^{\circ} \mathrm{N}$. In the northern box the freshwater is sent to the Atlantic and the Nordic Seas, but not to the Pacific (see Marti et al. 2010 for details).

A description of the model's ability to reproduce the mean climate, climate variability and various climatic events can be found in Marti et al. (2010). The ability of the model to reproduce the seasonal cycle in the tropics and ENSO is discussed in Braconnot et al. (2007a) and Guilyardi et al. (2009a) respectively. In general, seasonality is well reproduced over the ocean except that, during boreal summer, the North American monsoon doesn't penetrate far enough onto the continent, which slightly impacts on the location of the summer ITCZ in the east Pacific (Braconnot et al. 2007a). The model has similar biases to other models of this class, such as a warm bias along the east Pacific upwelling and a tendency of the equatorial upwelling to penetrate too far west in the western Pacific (Latif et al. 2001). This explains why the pattern of interannual variability is slightly shifted to the west compared to observations (Fig. 1). However several analyses have shown that ENSO variability is reasonably well reproduced 
(a) PI CTRL

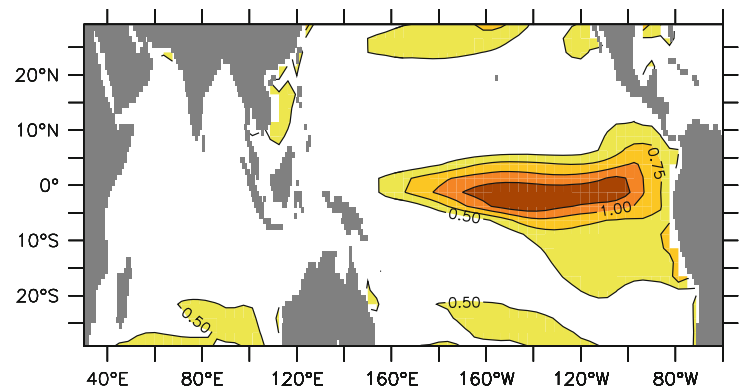

(c)

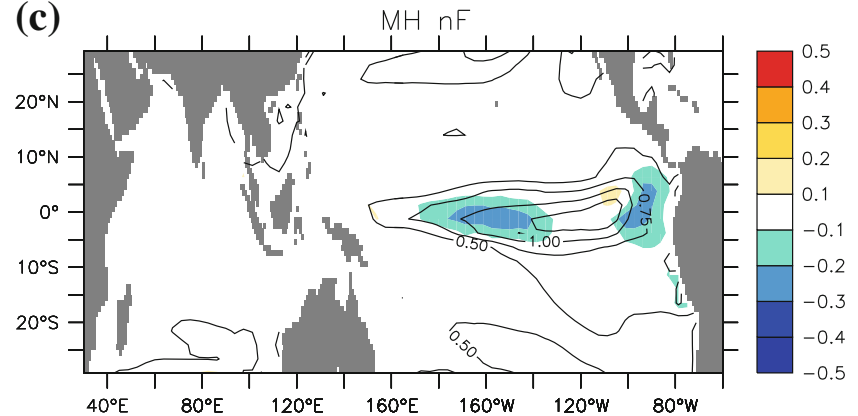

(e)

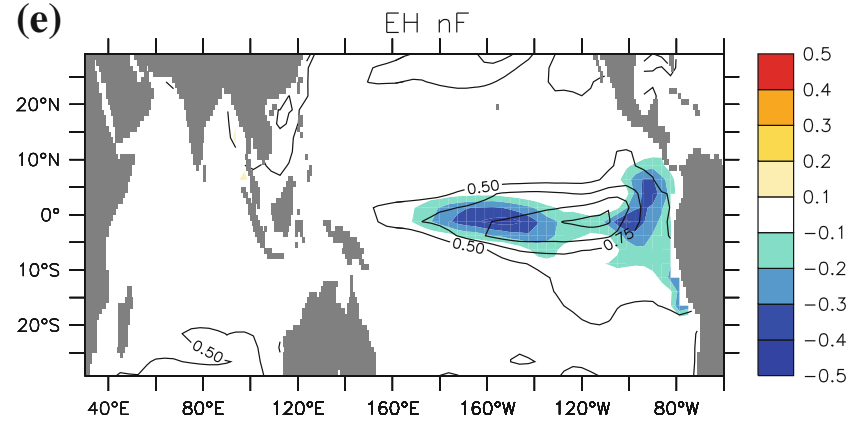

Fig. 1 Standard deviation $\left({ }^{\circ} \mathrm{C}\right)$ of boreal winter (DJF) of SST standard deviation $\left({ }^{\circ} \mathrm{C}\right)$ in the Pacific and the Indian sectors for a the pre-industrial (PI CTRL) simulation, b the HadiSST observations (Rayner et al. 2003) c the $6 \mathrm{ka}$ simulation with insolation forcing,

compared to other models in the same category (Guilyardi 2006; Leloup et al. 2008). The model also exhibits insufficient dynamical and thermodynamical coupling (Guilyardi et al. 2009a), which could lower its sensitivity to external forcings at the interannual time scale. These aspects should be considered when analysing the different simulations, and for these reasons, we do not pretend that our simulations are entirely realistic. Instead, we use them here as an integrating framework to discuss relative effects of insolation and freshwater fluxes on ENSO and mean state characteristics.

\subsection{Simulations of the early and mid-Holocene} with the IPSL-CM4 general circulation model

We first consider simulations for which only the changes in the Earth's orbital parameters are accounted for to discuss (b) Obs

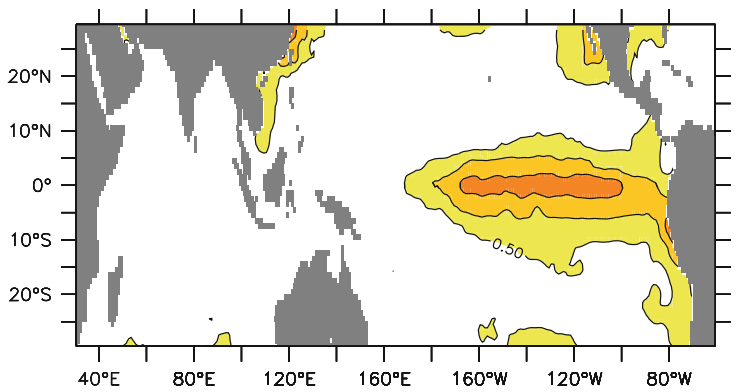

(d)

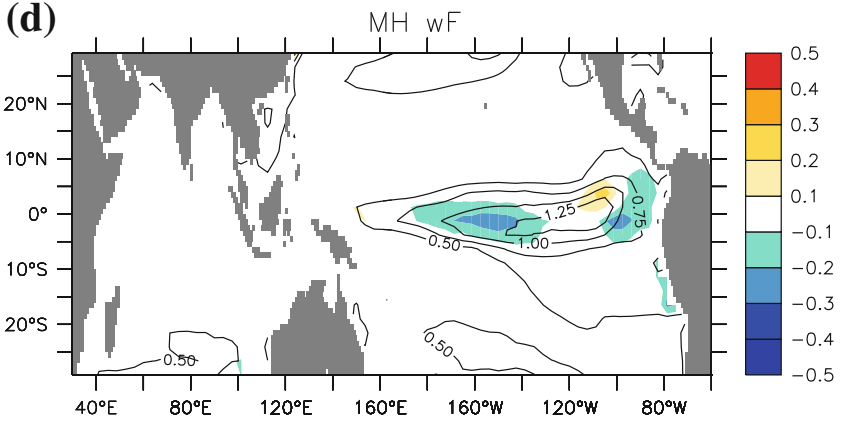

(f)

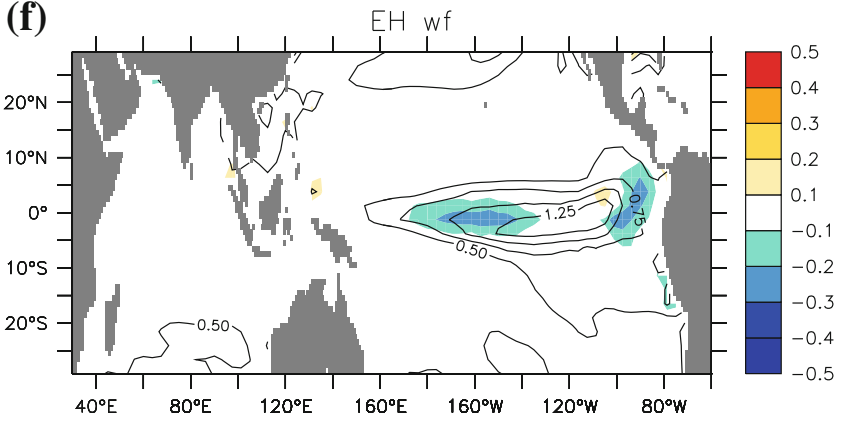

d the 6 ka simulation with insolation forcing and ice melting, e the $9.5 \mathrm{ka}$ simulation with insolation forcing, and $\mathbf{f}$ the $9.5 \mathrm{ka}$ with insolation forcing and ice melting

the impact of the insolation forcing for the Early Holocene (9,500 years ago, $9.5 \mathrm{ka})$ and the mid Holocene (6,000 years BP, $6 \mathrm{ka})$. These simulations were first designed to analyze the response of the African and Indian monsoon to insolation forcing (Marzin and Braconnot 2009; Braconnot et al. 2008). The Earth's orbital parameters were computed following Berger (1978). The midHolocene simulation corresponds to the PMIP simulation (Braconnot et al. 2007b). In two additional simulations, we also switch on the crude parameterization of ice-sheet melting (Table 1). The freshwater amount corresponds to $0.40 \mathrm{~mm} / \mathrm{year}$ sea level rise for mid Holocene and $0.63 \mathrm{~mm} /$ year for Early Holocene, representing the upper boundary of possible values. We do not consider in these simulations changes in the land-sea mask resulting from lower early Holocene sea level and that has been shown to impact the monsoon characteristics in the Indonesian sector 
Table 1 Sea-surface temperature characteristics (mean and interannual variability) in the Niño 3 box $\left(150^{\circ} \mathrm{E}-90^{\circ} \mathrm{E} ; 5^{\circ} \mathrm{S}-5^{\circ} \mathrm{N}\right)$ for the different simulations

\begin{tabular}{|c|c|c|c|c|c|}
\hline & PI & $6 \mathrm{ka}$ & $6 \mathrm{ka} \mathrm{wF}$ & $9.5 \mathrm{ka}$ & $9.5 \mathrm{ka} \mathrm{wF}$ \\
\hline Length of simulation (years) (number of year considered in this study) & 1,000 & 650 & 800 & 500 & 280 \\
\hline Mean SST value $\left({ }^{\circ} \mathrm{C}\right)$ (error bar) & $26.2(0.03)$ & $26.0(0.11)$ & $26.0(0.06)$ & $26.0(0.08)$ & $25.9(0.07)$ \\
\hline Mean magnitude of seasonal cycle $\left({ }^{\circ} \mathrm{C}\right)$ (error bar) & $2.6(0.9)$ & $1.94(0.5)$ & $1.93(0.5)$ & $2.14(0.4)$ & $2.07(0.45)$ \\
\hline Mean number of El Niño event/century threshold $1.2 \sigma(1.5 \sigma)$ & $11.2(5.5)$ & $9.1(6.4)$ & $10.1(4.7)$ & $6.2(4.6)$ & $10(7)$ \\
\hline Mean El Niño magnitude in Niño 3 threshold $1.2 \sigma(1.5 \sigma)$ & $2.55(2.84)$ & $2.48(2.55)$ & $2.0(2.63)$ & $2.0(2.14)$ & $2.26(2.51)$ \\
\hline Number of La Niña events/century threshold $1.2 \sigma(1.5 \sigma)$ & $11.5(5.5)$ & $3.7(2.3)$ & $7.1(5.9)$ & $5.1(3.2)$ & $7(6)$ \\
\hline Mean La Niña magnitude in Niño 3 threshold $1.2 \sigma(1.5 \sigma)$ & $3.11(3.56)$ & $2.96(2.91)$ & $3.25(3.5)$ & $2.95(3.07)$ & $3.34(2.64)$ \\
\hline
\end{tabular}

PI stands for the pre-industrial climate, 6 and $9.5 \mathrm{ka}$ for the climate of the mid and of the early Holocene respectively, and $\mathrm{wF}$ for the interactive ice-sheet melting freshwater flux in the north Atlantic. The mean magnitude of the seasonal cycle is obtained by computing first the magnitude of the seasonal cycle for each year and then the average. The error bars are estimated by bootstrapping over periods of 30 years. The characteristics of the El Niño and La Niño events are estimated from DFJ interannual variability

(Griffiths et al. 2009). Our simulations are therefore primarily conceptual and do not pretend to be realistic. The simulations are 280-800 year long, and the reference is a 1,000 year long simulation of the pre-industrial climate (Table 1). For the analyses, we have used monthly time series from the last part of the simulations where the climate characteristics are stable and no longer affected by the initial adjustment to the forcing. This corresponds to 770 years for the control simulations and varies from 100 to 370 years for the other simulations depending on their total length. The simulated changes for mid-Holocene ENSO resemble those of other PMIP2 simulations, even though the magnitude of the change in the Niño3 box interannual DJF SST variance is slightly smaller (Zheng et al. 2008). To first order, the reduction of ENSO magnitude is compatible with the estimates from proxy records reported in Table 2 . The current simulation was completed after files were included in the PMIP2 database, and the results presented here cover longer time series and a wider range of ENSO possibilities, which is needed to properly characterize interannual variability (Rodgers et al. 2004).

\section{Characteristics of interannual variability and seasonality in response to insolation forcing and freshwater fluxes}

The change in the Earth's orbital parameters does not alter the annual mean insolation, but modifies the latitudinal gradients and the shape of the seasonal cycle (Berger 1988). The orbital forcing change reduces the DecemberJanuary-February (DJF) SST interannual variability in the East Pacific for the early and the mid Holocene (Table 1; Fig. 1), confirming the results of previous studies (Clement et al. 2000; Zheng et al. 2008; Timmermann et al. 2007a). For each time period considered here, the interannual variability was enhanced when ice-sheet melting is accounted for (Fig. 1) as found for modern (Timmermann et al. 2007b) or glacial conditions (Merkel et al. 2010). In the following section, we further distinguish warm El Niño and cold La Niña events as done in Bush (Bush 2007) to infer possible asymmetry in the response to the different forgings.

\subsection{ENSO composites}

In order to compare the relative impact of the changes in the seasonality, El Niño or La Niña events on the SST evolution across the Holocene depending on the climate we classified the years from each simulation into El Niño, La Niña. The years that do not fall into the previous two categories are considered as normal year from which we can estimate a mean seasonal cycle. For a given simulation, a particular year is assigned to a El Niño (La Niña) year if the SST departure from the long term DJF average in the Niño3 box $\left(150^{\circ} \mathrm{W}-90^{\circ} \mathrm{W} ; 5^{\circ} \mathrm{S}-5^{\circ} \mathrm{N}\right)$ is larger (smaller) than 1.2 standard deviation $(\sigma)$ of the PI time series $\left(1.2^{\circ} \mathrm{C}\right.$, Table 1). We also consider $1.5 \sigma$ of each simulation to identify the biggest events in each time period and to test the robustness of the results. For a given climatic period a typical El Niño or La Niña year was then obtained by averaging all the corresponding El Niño (La Niña) years. We only discuss here features that remain robust whatever the criteria.

In response to the early and mid-Holocene insolation forcing, the development phase of $\mathrm{El} \mathrm{Niño} \mathrm{events} \mathrm{is}$ damped from August to November (Fig. 2). The figure shows a large diversity in the development of the El Niño events between the simulations. Figure 4 shows, for each simulation, the statistical significance of the monthly change of typical El Niño and La Niña years in the Niño3 box $\left(150^{\circ} \mathrm{W}-90^{\circ} \mathrm{W} ; 5^{\circ} \mathrm{S}-5^{\circ} \mathrm{N}\right)$. The evolution of the typical El Niño year and the standard deviation for each month is estimated from the average of all the El Niño or La Niña 
Table 2 Syntheses of the different studies used to infer the changes in temperature, precipitation and variability during early to midHolocene (Stott et al. 2004; Shulmeister and Lees 1995; Turney et al. 2004; Riedinger et al. 2002; Koutavas et al. 2006; Partin et al. 2007;
Benway et al. 2006; Kienast et al. 2006; Pahnke et al. 2007; Koutavas et al. 2002; Tudhope et al. 2001; Rodbell 1999; Moy et al. 2002; Haug et al. 2001; Lea et al. 2000)

\begin{tabular}{|c|c|c|c|c|c|c|c|}
\hline & Site & Region & Proxy & Climate parameter & 6 ka change & Record length & Reference \\
\hline 1 & MD98-2181 & $\begin{array}{r}\text { Western } \\
\text { Pacific }\end{array}$ & Foraminifer $\mathrm{Mg} / \mathrm{Ca}$ & Annual SST & $\begin{array}{l}\text { Warmer } \\
\text { SSTs }\end{array}$ & $0-15 \mathrm{ka}$ & Stott et al. (2004) \\
\hline 2 & MD98-2176 & $\begin{array}{r}\text { Western } \\
\text { Pacific }\end{array}$ & Foraminifer $\mathrm{Mg} / \mathrm{Ca}$ & Annual SST & $\begin{array}{l}\text { Warmer } \\
\text { SSTs }\end{array}$ & $0-15 \mathrm{ka}$ & Stott et al. (2004) \\
\hline 3 & Core V21-30 & $\begin{array}{l}\text { Eastern } \\
\text { Pacific }\end{array}$ & Foraminifer $\mathrm{Mg} / \mathrm{Ca}$ & Annual SST & Colder SSTs & $0-30 \mathrm{ka}$ & $\begin{array}{l}\text { Koutavas et al. } \\
\text { (2002) }\end{array}$ \\
\hline 4 & Groote Eylandt & $\begin{array}{l}\text { North } \\
\text { Australia }\end{array}$ & Pollen & $\begin{array}{l}\text { Effective precipitation } \\
\text { (summer monsoon) }\end{array}$ & $\begin{array}{l}\text { Wetter } \\
\text { conditions }\end{array}$ & $0-30 \mathrm{ka}$ & $\begin{array}{l}\text { Shulmeister and } \\
\text { Lees (1995) }\end{array}$ \\
\hline 5 & Lynch's crater & $\begin{array}{r}\text { North-East } \\
\text { Australia }\end{array}$ & Pollen & $\begin{array}{l}\text { Surface moisture (SE-trade } \\
\text { winds) }\end{array}$ & $\begin{array}{l}\text { Wetter } \\
\text { conditions }\end{array}$ & $0-45$ la & $\begin{array}{l}\text { Turney et al. } \\
\text { (2004) }\end{array}$ \\
\hline 6 & $\begin{array}{l}\text { Papua New Guinea } \\
\text { corals }\end{array}$ & $\begin{array}{l}\text { Papua New } \\
\text { Guinea }\end{array}$ & Coral 5180 & $\begin{array}{l}\text { Monthly SST/monthly } \\
\text { rainfall }\end{array}$ & $\begin{array}{l}\text { Reduced } \\
\text { variability }\end{array}$ & $\begin{array}{l}0-130 \mathrm{ka} \\
\quad \text { (partial } \\
\text { records) }\end{array}$ & $\begin{array}{l}\text { Tudhope et al. } \\
\text { (2001) }\end{array}$ \\
\hline 7 & Laguna Pallcacocha & Ecuador & Sediment gray scale & $\begin{array}{l}\text { Storm events (zonal SST } \\
\text { gradient) }\end{array}$ & $\begin{array}{l}\text { Reduced } \\
\text { variability }\end{array}$ & $0-15 \mathrm{ka}$ & Rodbell (1999) \\
\hline 8 & Laguna Pallcacocha & Ecuador & $\begin{array}{l}\text { Sediment red } \\
\text { intensity }\end{array}$ & $\begin{array}{l}\text { High SSTs (increased } \\
\text { inorganic sediments) }\end{array}$ & $\begin{array}{l}\text { Reduced } \\
\text { variability }\end{array}$ & $0-11 \mathrm{ka}$ & Moy et al. (2002) \\
\hline 9 & Galapagos islands & $\begin{array}{l}\text { Eastern } \\
\text { Pacific }\end{array}$ & $\begin{array}{l}\text { Siliciclastic/ } \\
\text { carbonate laminae }\end{array}$ & $\begin{array}{l}\text { El Niño intensity/ } \\
\text { frequency (rainfall) }\end{array}$ & $\begin{array}{l}\text { Reduced } \\
\text { variability }\end{array}$ & $0-6.1 \mathrm{ka}$ & $\begin{array}{l}\text { Riedinger et al. } \\
(2002)\end{array}$ \\
\hline 10 & Cariaco Basin & $\begin{array}{l}\text { Venezuela } \\
\text { coast }\end{array}$ & $\begin{array}{l}\text { Sediment titanium } \\
\text { concentration }\end{array}$ & $\begin{array}{l}\text { ITCZ position } \\
\text { (precipitation/river } \\
\text { discharge) }\end{array}$ & $\begin{array}{l}\text { ITCZ } \\
\text { northward } \\
\text { shift }\end{array}$ & $0-14 \mathrm{ka}$ & $\begin{array}{l}\text { Haug et al. } \\
\quad(2001)\end{array}$ \\
\hline 11 & Core $19-28$ & $\begin{array}{l}\text { Eastern } \\
\text { Pacific }\end{array}$ & Foraminifer $\mathrm{Mg} / \mathrm{Ca}$ & Annual SST & Colder SSTs & $2-12 \mathrm{ka}$ & $\begin{array}{l}\text { Koutavas et al. } \\
\text { (2006) }\end{array}$ \\
\hline 12 & Borneo Speleothem & Borneo & Speleothem 5180 & $\begin{array}{l}\text { Annual rainfall (little } \\
\text { modern seasonality) }\end{array}$ & $\begin{array}{l}\text { Wetter } \\
\text { conditions }\end{array}$ & $\begin{array}{l}0-27 \mathrm{ka} \\
\text { (partial } \\
\text { records) }\end{array}$ & $\begin{array}{l}\text { Partin et al. } \\
\text { (2007) }\end{array}$ \\
\hline 13 & $\begin{array}{l}\text { Core ME0005A-43JC/ } \\
\text { ODP site } 1242\end{array}$ & $\begin{array}{l}\text { Eastern } \\
\text { Pacific }\end{array}$ & Foraminifer 5180 & Sea surface salinity & $\begin{array}{l}\text { ITCZ } \\
\text { northward } \\
\text { shift }\end{array}$ & $0-30 \mathrm{ka}$ & $\begin{array}{l}\text { Benway et al. } \\
\text { (2006) }\end{array}$ \\
\hline 14 & TR163-19 & $\begin{array}{l}\text { Eastern } \\
\text { Pacific }\end{array}$ & Foraminifer $\mathrm{Mg} / \mathrm{Ca}$ & Annual SST & No change & $0-360 \mathrm{ka}$ & Lea et al. (2000) \\
\hline 15 & ODP Hole 806B & $\begin{array}{r}\text { Western } \\
\text { Pacific }\end{array}$ & Foraminifer $\mathrm{Mg} / \mathrm{Ca}$ & Annual SST & $\begin{array}{l}\text { Warmer } \\
\text { SSTs }\end{array}$ & $0-470 \mathrm{ka}$ & Lea et al. (2000) \\
\hline 16 & ME0005A-24JC & $\begin{array}{l}\text { Eastern } \\
\text { Pacific }\end{array}$ & $\begin{array}{l}\text { Alkenone } \\
\text { unsaturation index } \\
\text { U37 }\end{array}$ & Annual SST & Cooler SSTs & $0-35 \mathrm{ka}$ & $\begin{array}{l}\text { Kienast et al. } \\
\text { (2006) }\end{array}$ \\
\hline 17 & KNR176-JPC32 & $\begin{array}{l}\text { Eastern } \\
\text { Pacific }\end{array}$ & $\begin{array}{l}\text { Alkenone } \\
\text { unsaturation index } \\
\text { U37 }\end{array}$ & Annual SST & Cooler SSTs & $0-27 \mathrm{ka}$ & $\begin{array}{l}\text { Pahnke et al. } \\
\text { (2007) }\end{array}$ \\
\hline 18 & KNR176-JPC32 & $\begin{array}{l}\text { Eastern } \\
\text { Pacific }\end{array}$ & Alkenone 5D & Annual precipitation & $\begin{array}{l}\text { Wetter } \\
\text { conditions }\end{array}$ & $0-27 \mathrm{ka}$ & $\begin{array}{l}\text { Pahnke et al. } \\
\text { (2007) }\end{array}$ \\
\hline
\end{tabular}

The number in the first column refers to the numbers of the different sites in Fig. 7

events. We then compare this evolution between two simulations by testing for each month the null hypothesis that there is no difference between the two simulations. Figure 3 shows the results of the $t$ test obtained when the events are selected using the 1.2 $\sigma$ SST threshold from the control simulation or when using the $1.5 \sigma$ SST threshold from each simulations (see Table 1). In the second case, only the major events are considered, but the statistics may be biased due to the small number of events in some of the simulations. We present the results of the $t$ test showing both the 5 and $10 \%$ confidence level (dotted lines). This figure shows that the reduced SST warming rate induced by insolation changes during the autumn preceding the peak warming are statistically significant from control for 9.5 
and $6 \mathrm{ka}$ in spring, which indicates that El Niño development is damped.

The freshwater flux simulations do not show significant differences for El Niño (Fig. 3). Although the differences between the simulations with and without freshwater flux are not statistically significant they show a consistent enhancement in the slope of the curve during the development phase of the events compared to the simulation without the freshwater flux (Fig. 2) and the reduction of the ENSO peak is shifted in time (Fig. 3). The effect of the freshwater flux almost counteracts the effect of the insolation forcing (Figs. 1, 2). Note also that La Niña events are significantly altered in all simulations, suggesting that these events were more affected by the different forcings and that these changes would have dominated SST variability in the Holocene. This may have been important during the Early Holocene and careful analyses of proxy records is therefore needed to estimate which of the forcing may have been the most important in shaping interannual variability depending on proxy location.
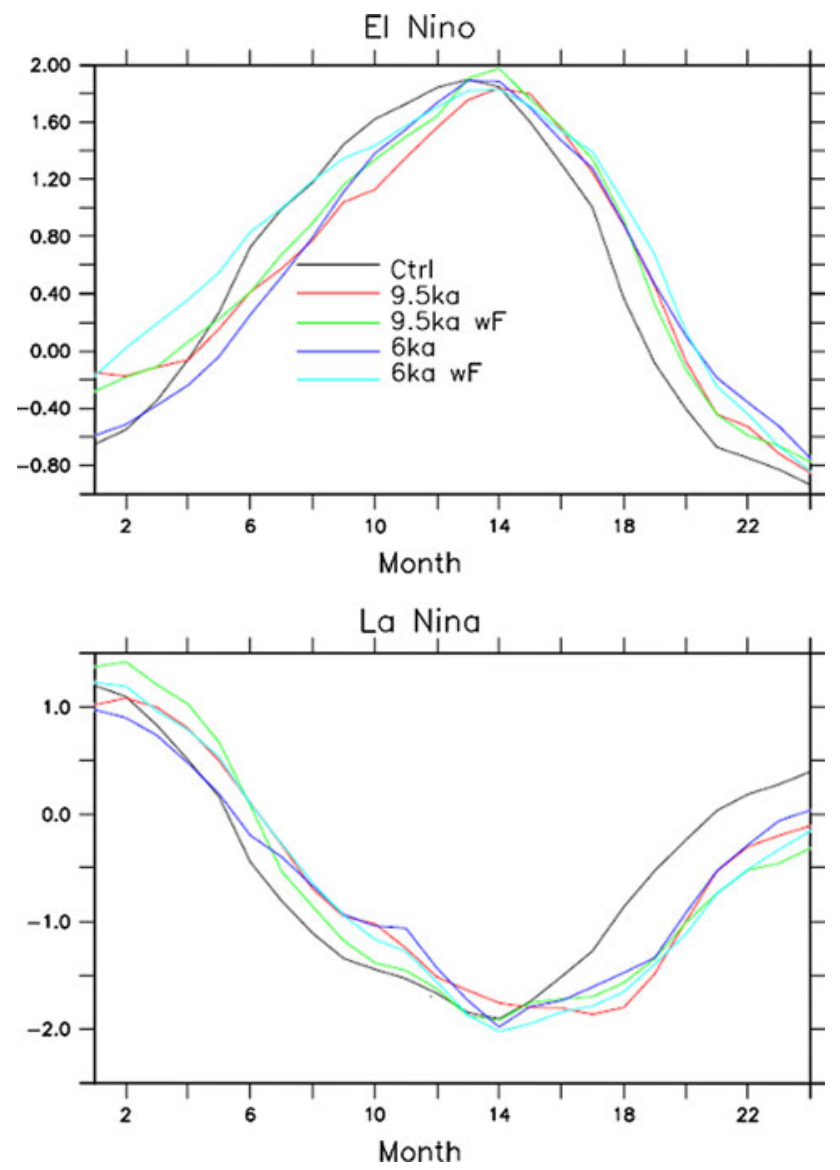

Fig. 2 Evolution of Niño3 SST $\left({ }^{\circ} \mathrm{C}\right)$ for composite El Niño (top) and La Niña years (bottom) for the different simulations. The time axis considers the year of the event (1-12) and the year following the event (13-24)
The number of events is reduced (Table 1), with a greater reduction found for the Early Holocene for warm events and in the mid-Holocene for cold events. In our simulations, La Niña events also have longer persistence compared to PI with differences of up to $0.8^{\circ} \mathrm{C}$ the following spring (Fig. 2). While the magnitude of this change may not reflect reality, it highlights that the response of warm and cold events is not symmetrical, and shows that a decomposition of the variability into typical events is needed to properly assess the changes in interannual variability. It also suggests that different changes in warm and cold events may result in similar changes in interannual variability, which has implications for how changes in these events impact the environment. The asymmetry of the response could also be at the origin of differences between proxy records, depending on whether these proxy are more sensitive to cold or warm events.

\subsection{Changes in seasonality}

To fully assess the SST changes, we also need to consider changes in seasonality. The insolation forcing leads to colder (warmer) SSTs from January to May (August to November). As found in De Willt and Schneider (deWitt and Schneider 2000), the West Pacific changes in annual mean cycle are dominated by the changes in the heat fluxes, whereas changes in winds play a larger role in the eastern Pacific. In the east Pacific, dynamical forcing helps dampen the equatorial upwelling (Fig. 4). The increased boreal summer insolation in the north hemisphere causes both the interhemispheric and land-sea temperature gradients to be strengthened, thereby enhancing the monsoon winds from the warm and humid tropical ocean onto the continents. The Indian and Southeast Asian monsoon are enhanced during the early and mid-Holocene, and as are the trade winds in the middle and western Pacific (Fig. 5). In the eastern Pacific, the North American monsoon also strengthens. However, windstress increases mostly from the subtropical north Pacific and not from the equator (Fig. 5). In this region, the northward component of the windstress across the equator is a key driver of the upwelling near the coast (Xie et al. 2008), so that a coupled simulation with a stronger northward windstress in this region will show stronger upwelling than a simulation with stronger zonal flow (Braconnot et al. 2007a). Our simulations of mid and Early Holocene simulations exhibit a reduced windstress in the east Pacific (Fig. 5), which dampens the development of the equatorial upwelling, even though the southeast trade wind is stronger further west. In addition there is a slight southward shift of the rain belt on the Panama Isthmus and in the east Pacific north of the equator. 
(a)

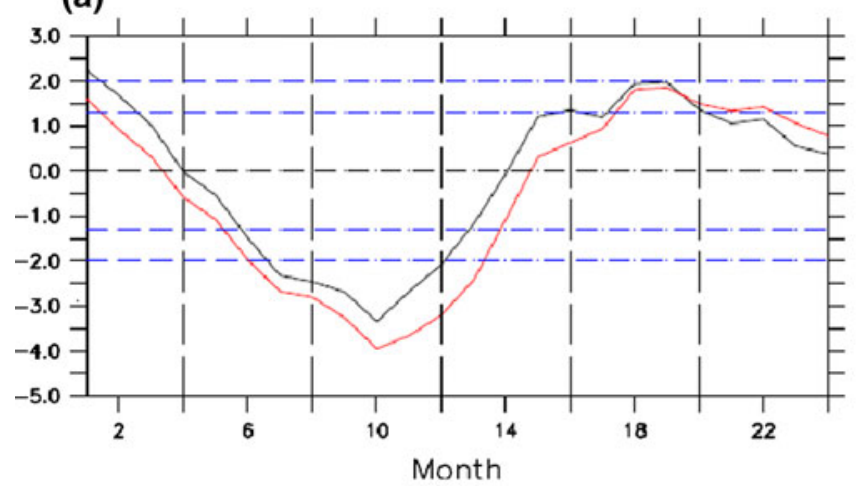

(b)

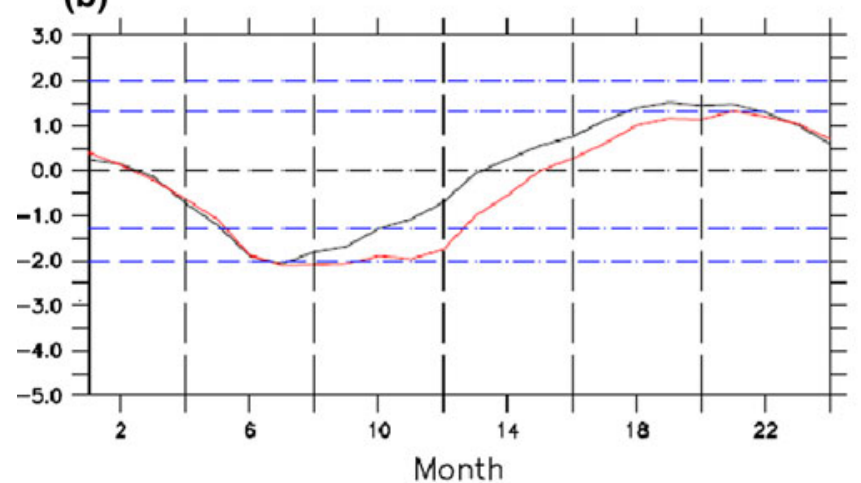

(c)

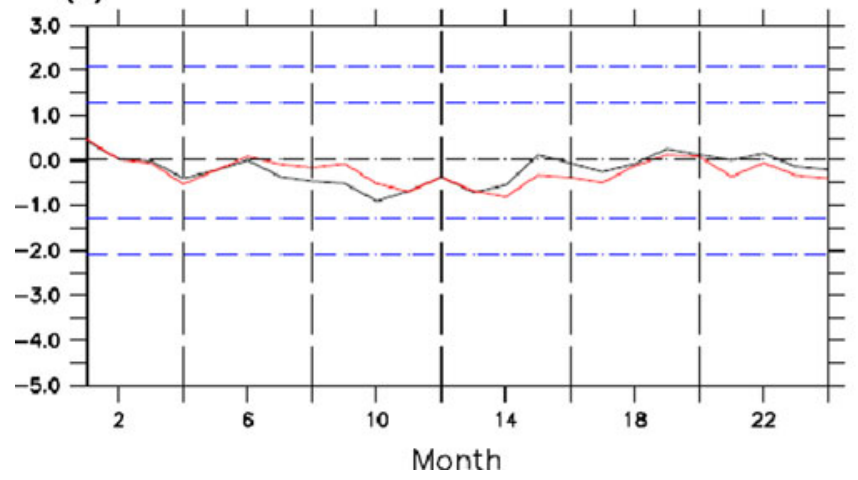

Fig. $3 T$ test estimates for the evolution of the differences between the typical El Niño events (left) and La Niña events (right) estimated from the composite analyses of the SST time series in the Niño3 box for a $9.5 \mathrm{ka}$ and CTRL, b $6 \mathrm{ka}$ and CTRL and $\mathbf{c} 9.5 \mathrm{ka} w F$ and $9.5 \mathrm{ka}$. Negative (positive) values indicate that the magnitude is smaller

A freshwater flux in the Northern Atlantic cools SSTs, resulting in anticyclonic circulation and a strengthening of the northerly flow across the Panama Isthmus (Timmermann et al. 2007b; Swingedouw et al. 2009). This shifts the ITCZ southward in the east Pacific, which reduces the monsoon precipitation over land and induces an anomalous southward circulation in the east. This effect further dampens the development of the equatorial upwelling (Xie et al. 2008). This effect on the seasonal cycle is smaller than the impact of the orbital forcing (Fig. 4). In our simulations, the reduction of the wind is at its highest near the coast for the insolation
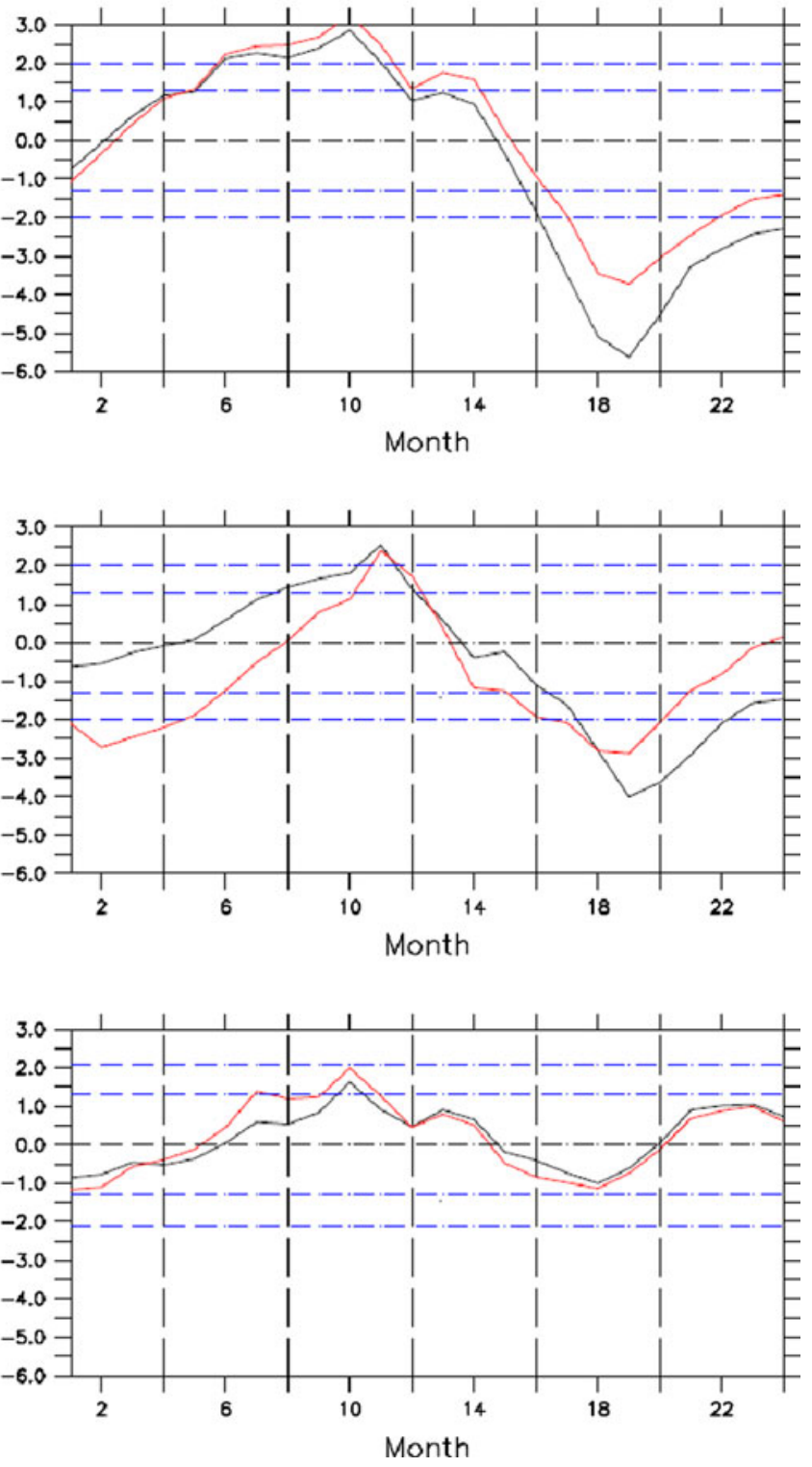

(larger) in the past than in the reference simulation. The black line and the red line stand respectively for El Niño events selected using the $1.2 \sigma$ (black) and $1.5 \sigma$ (red) threshold in SST. The 5 and $10 \%$ confidence limits are provided (horizontal dotted lines) for the $1.2 \sigma$ threshold. They are quite similar for the $1.5 \sigma$ threshold (not shown)

forcing, but not for the freshwater forcing. This explains why the effect of the north Atlantic freshwater flux on the east Pacific seasonality and on the upwelling development is less than the effect of the insolation forcing.

Interestingly, the Early Holocene shows greater differences in SST relative to present day, but the mid-Holocene has a greater change in the magnitude of the seasonal cycle (difference from minimum to maximum SST values; Table 1). This differential rate of change of various aspects of the climate system in the past is important for the interpretation of proxy data. For example, a proxy which is 


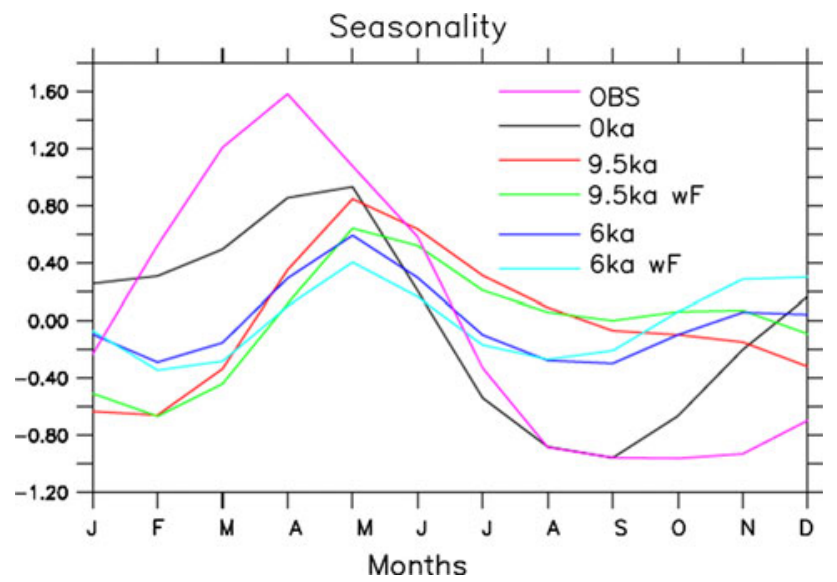

Fig. 4 Seasonal cycle of SST (annual mean removed, ${ }^{\circ} \mathrm{C}$ ) in the Niño 3 box $\left(150^{\circ} \mathrm{E}-90^{\circ} \mathrm{E}, 5^{\circ} \mathrm{S}-5^{\circ} \mathrm{N}\right)$ for the different simulations and the HadiSST observations

limited by the seasonal range of SSTs, may be used to reconstruct Summer SST, due to a strong modern correlation between these two climate parameters. However, these results show that modern correlations between different aspects of the climate system do not necessarily hold true in the past, and emphasizes the need to better understand the limiting factors for any proxy.

(a)

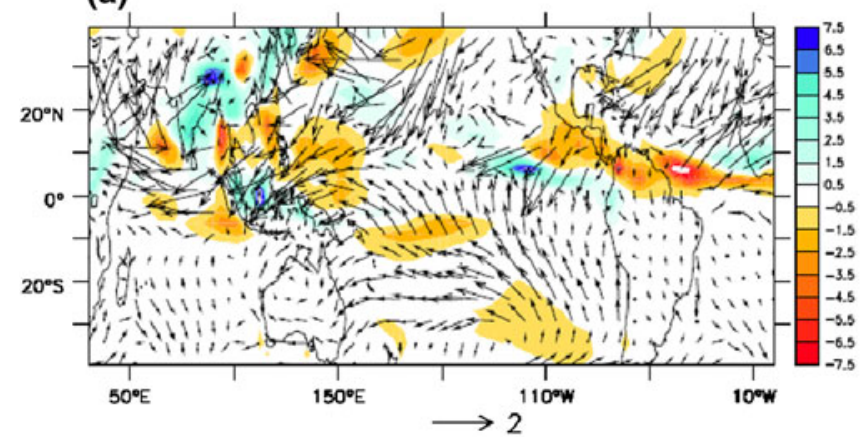

(c)

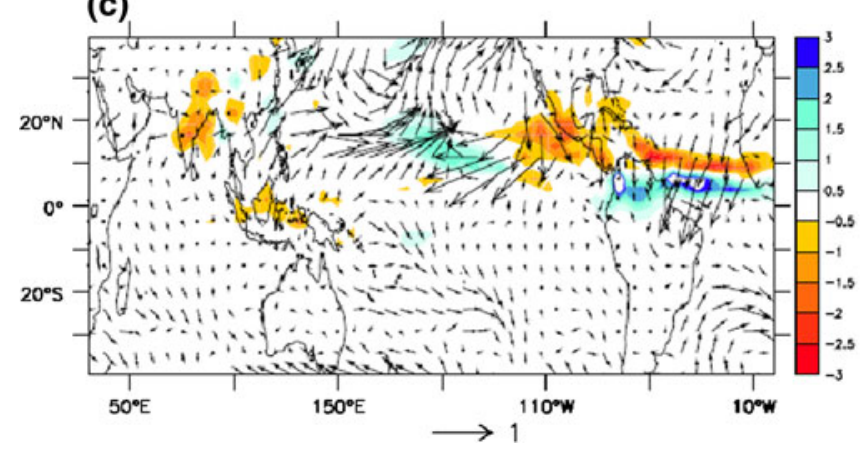

Fig. 5 Wind $(\mathrm{m} / \mathrm{s})$ and precipitation $(\mathrm{mm} /$ day) changes for JulyAugust. Differences between a $9.5 \mathrm{ka}$ and CTRL, b $6 \mathrm{ka}$ and CTRL, c $9.5 \mathrm{ka} \mathrm{wF}$ and $9.5 \mathrm{ka}$ and $\mathbf{d} 6 \mathrm{ka} \mathrm{wF}$ and $6 \mathrm{ka}$. Note that for clarity

\section{Relative SST changes in seasonality and interannual variability}

The analysis of the SST changes in the Niño 3 box (Fig. 2) show that it is difficult to obtain a simple view of the relative importance of the SST changes for seasonality and interannual variability. In order to summarize the results and to extend it to the whole equatorial Pacific, we computed at each grid point the root mean square difference from July preceding the event to July following the event between the composites of the different simulations. In the case of normal years this provides integrated information of the changes in the mean seasonal cycle. Figure 6 illustrates the results for the Early Holocene. The top figure shows for each model grid point the root mean square difference between the El Niño anomalies of $9.5 \mathrm{ka}$ and those of PI for SST (isolines) and precipitation (color). These differences can be compared to those obtained for $\mathrm{La}$ Niña event or for Normal years, the latter representing changes in seasonality. We further summarize the results obtained for SST by averaging the SST rms in 3 boxes along the equatorial Pacific (Fig. 7).

Figure 7 also provides a pan equatorial Pacific view of available studies reporting mid to Early Holocene changes in the mean state and interannual variability. These studies

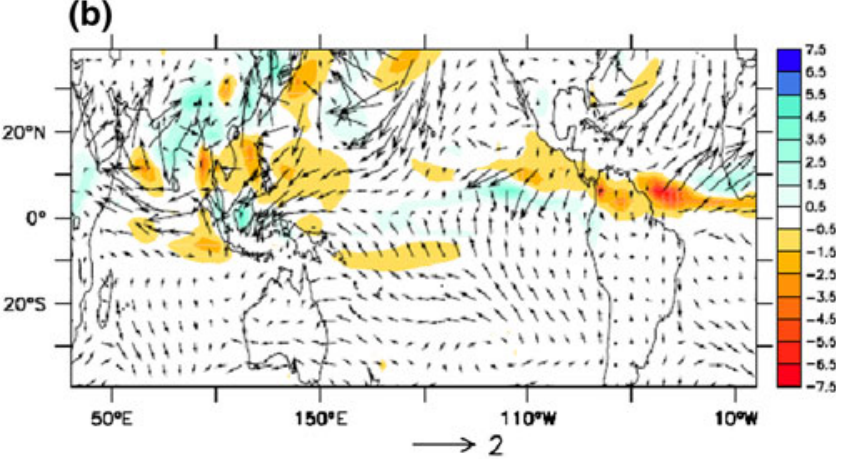

(d)

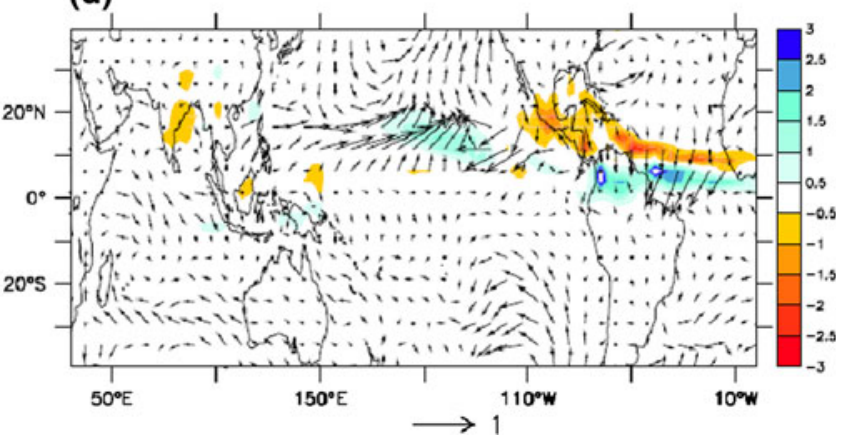

the bottom and top panels have different color scales and different reference lengths for the wind vectors 


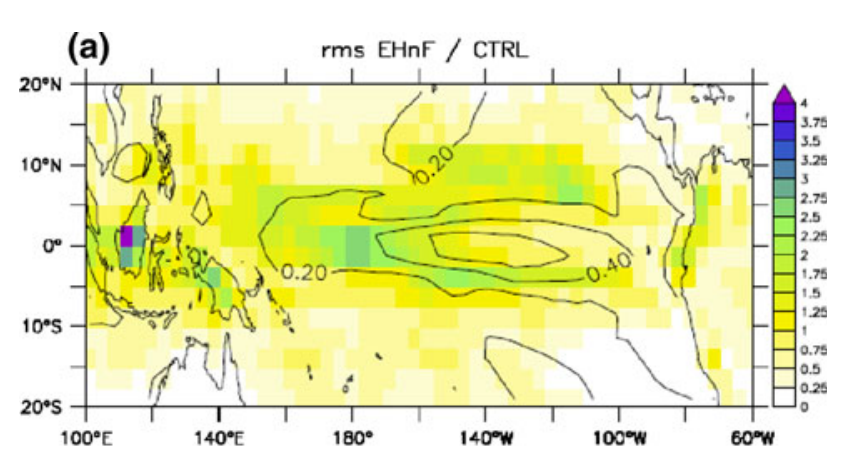

(b)

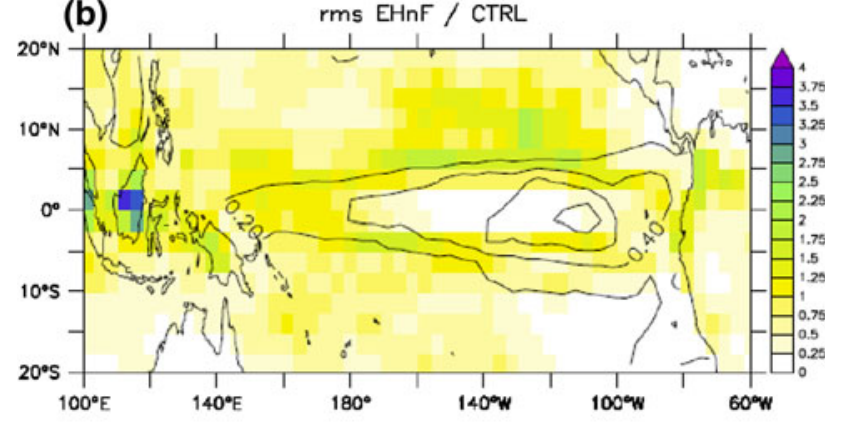

(c)

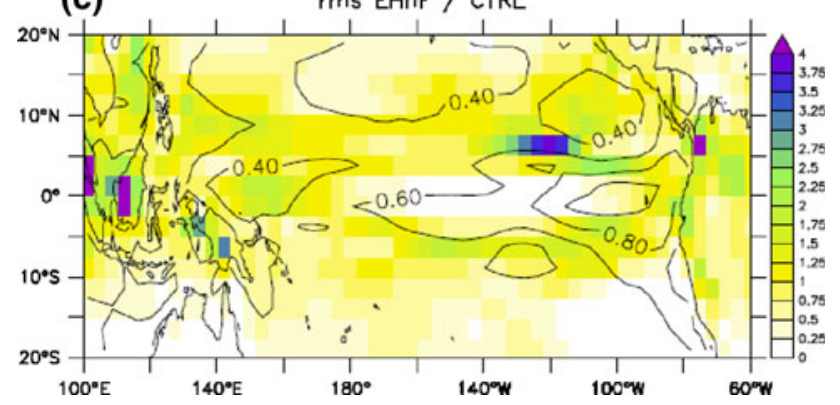

Fig. 6 Root mean square $(r m s)$ difference between $9.5 \mathrm{ka}$ and PI from July to July around a the peak ENSO event, b the peak Niña event and c normal year (seasonal cycle) for SST (isolines) and precipitation (color). Rms is plotted every $0.2^{\circ} \mathrm{C}$ for SST, starting at 0.2 to only consider relevant features

consider different types of proxy that account for changes in sea-surface temperature, precipitation, or interannual to multidecadal variability, including shifts of the Intertropical Convergence Zone (Table 2). They provide a consistent picture of SST and hydrological changes across the Pacific that can be used for model assessment. These records support the view that ENSO variability was reduced (Moy et al. 2002) or even absent in the early to mid-Holocene (Sandweiss et al. 1996), and that mean conditions were closer to a La Niña state. It is however difficult to directly compare our model results with these reconstructions. In particular reconstructed warmer SSTs in the west and colder SSTs in the east are not shown in the simulated annual mean SST, but instead match the simulated change in SST mean annual cycle. It is therefore important to better know which signal is reflected by the proxy data.
The wetter conditions reconstructed in the north of Australia are shown in our mid-Holocene simulation, but the magnitude is reduced. As stated by Brown et al. (2008) some of the model biases in the west Pacific such as the westward extension of the cold tongue and the overly zonal position of the SPCZ limits model-data comparisons in these regions. However, the results shown in Fig. 7 may also reflect a combination of changes in annual mean climate, seasonality or interannual variability, depending on the location of the proxy records and the factors that control or limit their expression, as suggested by our comparison of the relative effect of insolation and freshwater flux on seasonality and variability.

The plots in Fig. 7 show that the change in seasonality is the dominant cause of SST changes throughout the Holocene. Cold events have a larger impact than warm events, and the relative size varies depending on precession $(6 \mathrm{ka}$ larger than $9.5 \mathrm{ka}$ ). The impact of freshwater forcing is of similar magnitude to the insolation forcing. The regional differences are more easily inferred from the maps (Fig. 6). For $9.5 \mathrm{ka}$, the larger differences in the development of typical El Niño events are found in the east Pacific, as expected for SST. The center of these differences is located slightly to the west, whereas the larger differences for seasonality are more confined to the coast. Changes in seasonality are thus dominant across the Holocene and even offset the impact of changes in variability in those regions where SST fluctuations are dominated by interannual variability in the modern climate.

These maps allow comparisons to be made between the precipitation signal and the temperature signal, even though precipitation is noisier than SST and the error bars larger. Interestingly, precipitation is more affected by El Niño events in most of the tropical Pacific Ocean. Following the usual pattern of precipitation anomalies associated with El Niño or La-Niña events, the largest differences in precipitation are found in the west Pacific and the Indonesian archipelago and along the Andes and South America (Fig. 6). However Fig. 6 shows that the freshwater signal should be analysed with care in the west Pacific where seasonality and interannual variability have an impact of similar amplitude in several places. This reflects the large imprint of the changes in the seasonal variations of the ITCZ in these regions. These results clearly show that the response of $\mathrm{El}$ Niño, La Niña and seasonality to the insolation forcing has different relative impact depending on the location and variable considered (SST, precipitation).

\section{Conclusion}

Our simulations of the Early and mid-Holocene that examine the impact of both changes in insolation and the 


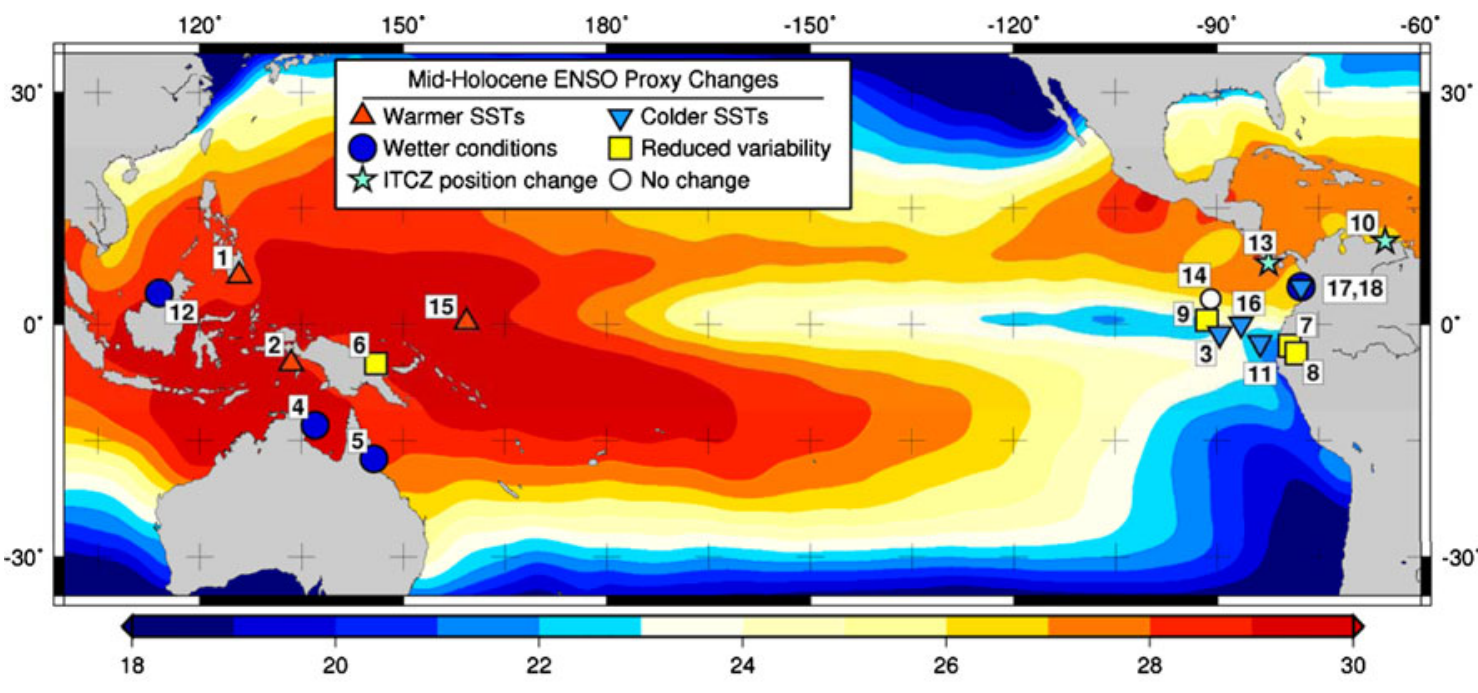

$120^{\circ} \mathrm{E}-160^{\circ} \mathrm{E}$

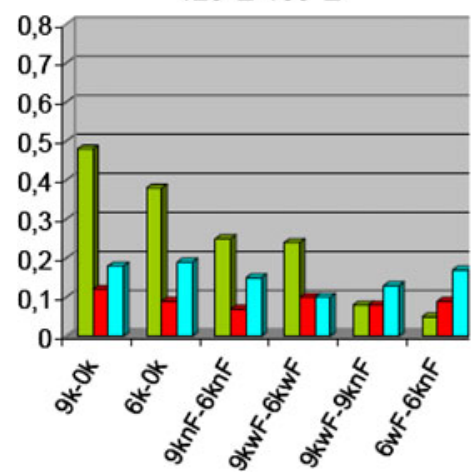

Fig. 7 Location of ENSO proxy sites with general information on climate change inferred from the synthesis provided in Table 2: triangles: warmer SSTs; inverted triangles: cooler SSTs; circles: increased precipitation; squares: reduced ENSO variability; stars: positional change of ITCZ. The background shows the distribution of modern SSTs during the recent La Niña event of December 1998 (data taken from the Reynolds global SST dataset at NOAA CDC: http://www.cdc.noaa.gov/). Below: The boxes summarize the relative

melting of the ice-sheet provide a consistent framework to analyse the relative importance of these two forcings on the mean seasonal cycle and interannual variability in the Pacific Ocean.

An interesting feature emerges in the results that question the frequency entrainment between a strong seasonal forcing and ENSO that may be inferred locally from the strength of the seasonal cycle in the eastern Pacific SST (Timmermann et al. 2007b; Liu 2002). This mechanism supposes an inverse correlation between the strength of the seasonal cycle and the magnitude of the interannual variability. Here, orbital forcing and freshwater release both dampen the seasonal cycle in the east Pacific in the early and mid-Holocene, but the orbital forcing also dampens the interannual variability whereas the freshwater flux enhances it. The orbital forcing enhances both the interhemispheric and the land sea temperature contrast, impact of El Niño, La Niña and seasonality on the SST changes $\left({ }^{\circ} \mathrm{C}\right)$ across the Holocene, when considering only insolation or freshwater flux, as well as their interactions. The different bars correspond to the mean root mean square difference between the simulations listed on the $X$-axis computed from July to July so as to consider the whole development and decay phase of El Niño and La Niña events. The names of the simulation refer to Table 2

strengthening the southwesterly trade winds and the south and Asian monsoon flow in autumn, which counteracts the development of warm events (Fig. 2). The freshwater release leads to a smaller east-west SST gradient across the equatorial Pacific which favours the relaxation of trade winds and thereby El Niño events (Fig. 2). This needs to be further analyzed.

The slow variation of the insolation forcing during the Holocene has a larger impact on seasonality than the perturbation of the north Atlantic freshwater flux. These changes in seasonality have a larger impact on SST than changes in interannual variability, even in the east Pacific. A combination of dynamical and thermodynamical effects involving the large scale monsoon circulation and cross equatorial flow, the change in seasonality induced by the insolation forcing results in a dampening of seasonal SST variations compared to present day, and in a deeper 
thermocline. This underlines the need to carefully investigate the robustness of the calibration between proxy indicators and interannual variability in a changing climate, which may be achieved by careful model-data comparison. Proxies that are correlated with modern interannual variability may result in an overestimation of ENSO changes when changes in seasonality dominate the climate change.

The response of interannual variability to the freshwater release almost counteracts the effect of insolation. These results show that in order to fully understand seasonal and interannual variability of different regions of the Pacific, we require a better understanding of freshwater fluxes changes during the Holocene. This forcing may have offset the effect of insolation on variability in the Early Holocene, so that changes in ENSO variations may not have been recorded in many regions. The larger changes in seasonality and variability are found in the east Pacific where dynamical and thermodynamical effects enhance the SST response.

Apparent discrepancies between different proxy records (Koutavas et al. 2002; Sandweiss et al. 1996) or between model and data (Brown et al. 2008) may result from different sensitivity to annual mean cycle or interannual variability of temperature or precipitation. Taken with our results, these discrepancies highlight the need to reinvestigate these relationships by regions and by proxy using model results as an integrating framework. A multi-proxy integration considering these different aspects would be of great use to assess the realism of climate model and to better understand the link between seasonality and interannual variability, thus helping to improve climate predictability.

Acknowledgments Part of this study has been performed within the framework of the French National Research Agency ANR PICC project. The simulations have been performed on the NEC SX8 of the Commissariat à l'énergie atomique computing center (ccrt). We would like to thank Florian Arfeuil who started this work as part of his Master 2 training.

Open Access This article is distributed under the terms of the Creative Commons Attribution Noncommercial License which permits any noncommercial use, distribution, and reproduction in any medium, provided the original author(s) and source are credited.

\section{References}

Benway HM, Mix AC, Haley BA, Klinkhammer GP (2006) Eastern Pacific warm pool paleosalinity and climate variability: 0-30 kyr. Paleoceanography 21:PA3008. doi:10.1029/2005PA 001208

Berger A (1978) Long-term variations of caloric solar radiation resulting from the earth's orbital elements. Quat Res 9:139-167

Berger A (1988) Milankovitch theory and climate. Rev Geophys 26:624-657
Braconnot P, Hourdin F, Bony S, Dufresne JL, Grandpeix JY, Marti O (2007a) Impact of different convective cloud schemes on the simulation of the tropical seasonal cycle in a coupled oceanatmosphere model. Clim Dyn 29(5):501-520

Braconnot P, Otto-Bliesner B, Harrison S, Joussaume S, Peterchmitt JY, Abe-Ouchi A, Crucifix M, Driesschaert E, Fichefet T, Hewitt CD, Kageyama M, Kitoh A, Laine A, Loutre MF, Marti O, Merkel U, Ramstein G, Valdes P, Weber SL, Yu Y, Zhao Y (2007b) Results of Pmip2 coupled simulations of the midHolocene and last glacial maximum-part 1: experiments and large-scale features. Clim Past 3(2):261-277

Braconnot P, Marzin C, Gregoire L, Mosquet E, Marti O (2008) Monsoon response to changes in earth's orbital parameters: comparisons between simulations of the Eemian and of the Holocene. Clim Past Discuss 4:459-493

Brown J, Tudhope AW, Collins M, McGregor HV (2008) MidHolocene ENSO: issues in quantitative model-proxy data comparisons. Paleoceanography 23(3):PA3202. doi: 10.1029/2007pa001512

Bush ABG (2007) Extratropical influences on the El Nino-southern oscillation through the late quaternary. J Clim 20(5):788-800. doi: $10.1175 / \mathrm{Jcli} 4048.1$

Cane MA, Braconnot P, Clement A, Gildor H, Joussaume S, Kageyama M, Khodri M, Paillard D, Tett S, Zorita E (2006) Progress in paleoclimate modeling. J Clim 19(20):5031-5057

Clarke GKC, Leverington DW, Teller JT, Dyke AS (2004) Paleohydraulics of the last outburst flood from Glacial Lake Agassiz and the 8200 BP cold event. Quat Sci Rev 23(3-4):389-407. doi: 10.1016/j.quascirev.2003.06.004

Clement AC, Seager R, Cane MA (2000) Suppression of El Nino during the mid-Holocene by changes in the earth's orbit. Paleoceanography 15(6):731-737

Cobb KM, Charles CD, Cheng H, Edwards RL (2003) El Nino/ southern oscillation and tropical pacific climate during the last millennium. Nature 424(6946):271-276

deWitt DG, Schneider EK (2000) The tropical ocean response to a change in soar forcing. J Clim 13:1133-1149

Griffiths ML, Drysdale RN, Gagan MK, Zhao JX, Ayliffe LK, Hellstrom JC, Hantoro WS, Frisia S, Feng YX, Cartwright I, Pierre ES, Fischer MJ, Suwargadi BW (2009) Increasing Australian-Indonesian monsoon rainfall linked to early Holocene sea-level rise. Nat Geosci 2(9):636-639. doi:10.1038/ Ngeo605

Guilyardi E (2006) El Niño-mean state-seasonal cycle interactions in a multi-model ensemble. Clim Dyn 26(4):329-348

Guilyardi E, Braconnot P, Jin FF, Kim ST, Kolasinski M, Li T, Musat I (2009a) Atmosphere feedbacks during ENSO in a coupled GCM with a modified atmospheric convection scheme. J Clim 22(21):5698-5718. doi:10.1175/2009jcli2815.1

Guilyardi E, Wittenberg A, Fedorov A, Collins M, Wang CZ, Capotondi A, van Oldenborgh GJ, Stockdale T (2009b) Understanding El Nino in ocean-atmosphere general circulation models progress and challenges. Bull Am Meteorol Soc 90(3):325. doi:10.1175/2008bams2387.1

Haug GH, Hughen KA, Sigman DM, Peterson LC, Rohl U (2001) Southward migration of the intertropical convergence zone through the Holocene. Science 293(5533):1304-1308

Kienast M, Kienast SS, Calvert SE, Eglinton TI, Mollenhauer G, François R, Mix AC (2006) Eastern Pacific cooling and Atlantic overturning circulation during the last deglaciation. Nature 443:846-849

Koutavas A, Lynch-Stieglitz J, Marchitto TM, Sachs JP (2002) El Nino-like pattern in ice age tropical pacific sea surface temperature. Science 297(5579):226-230

Koutavas A, Demenocal PB, Olive GC, Lynch-Stieglitz J (2006) MidHolocene El Ninõ-Southern Oscillation (ENSO) attenuation 
revealed by individual foraminifera in eastern tropical pacific sediments. Geology 34(12):993-996

Latif M, Sperber K, Arblaster J, Braconnot P, Chen D, Colman A, Cubasch U, Cooper C, Delecluse P, DeWitt D, Fairhead L, Flato G, Hogan T, Ji M, Kimoto M, Kitoh A, Knutson T, Le Treut H, Li T, Manabe S, Marti O, Mechoso C, Meehl G, Power S, Roeckner E, Sirven J, Terray L, Vintzileos A, Voss R, Wang B, Washington W, Yoshikawa I, Yu J, Zebiak S (2001) Ensip: The El Nino simulation intercomparison project. Clim Dyn 18(3-4):255-276

Lea DW, Pak DK, Spero HJ (2000) Climate impact of late quaternary equatorial Pacific sea surface temperature variations. Science 289(5485):1719-1724

Leduc G, Vidal L, Tachikawa K, Rostek F, Sonzogni C, Beaufort L, Bard E (2007) Moisture transport across Central America as a positive feedback on abrupt climatic changes. Nature 445(7130): 908-911

Leloup J, Lengaigne M, Boulanger JP (2008) Twentieth century ENSO characteristics in the IPCC database. Clim Dyn 30(2-3):277-291. doi:10.1007/s00382-007-0284-3

Liu ZG (2002) A simple model study of ENSO suppression by external periodic forcing. J Clim 15(9):1088-1098

Liu ZY, Kutzbach J, Wu LX (2000) Modeling climate shift of El Nino variability in the Holocene. Geophys Res Lett 27(15):2265-2268

Marti O, Braconnot P, Dufresne JL, Bellier J, Benshila R, Bony S, Brockmann P, Cadule P, Caubel A, Codron F, de Noblet N, Denvil S, Fairhead L, Fichefet T, Foujols MA, Friedlingstein P, Goosse H, Grandpeix JY, Guilyardi E, Hourdin F, Idelkadi A, Kageyama M, Krinner G, Levy C, Madec G, Mignot J, Musat I, Swingedouw D, Talandier C (2010) Key features of the Ipsl ocean atmosphere model and its sensitivity to atmospheric resolution. Clim Dyn 34(1):1-26. doi:10.1007/s00382-0090640-6

Marzin C, Braconnot P (2009) Variations of Indian and African monsoons induced by insolation changes at 6 and $9.5 \mathrm{kyr}$ BP. Clim Dyn 33(2-3):215-231. doi:10.1007/s00382-009-0538-3

Meehl GA, Stocker TF, Collins WD, Friedlingstein P, Gaye AT, Gregory JM, Kitoh A, Knutti R, Murphy JM, Noda A, Raper SCB, Watterson IG, Weaver AJ, Zhao Z-C (2007) Global climate projections. In: Solomon S, Qin D, Manning M, Chen Z, Marquis M, Averyt KB, Tignor M, Miller HL (eds) Climate change 2007: the physical science basis. Contribution of working group I to the fourth assessment report of the Intergovernmental Panel on Climate Change. Cambridge University Press, Cambridge, UK and New York, NY, USA

Merkel U, Prange M, Schulz M (2010) ENSO variability and teleconnections during glacial climates. Quat Sci Rev 29(1-2):86-100. doi:10.1016/j.quascirev.2009.11.006

Moy CM, Seltzer GO, Rodbell DT, Anderson DM (2002) Variability of El Nino/southern oscillation activity at millennial timescales during the Holocene epoch. Nature 420(6912):162-165

Otto-Bliesner BL (1999) El Nino La Nina and Sahel precipitation during the middle Holocene. Geophys Res Lett 26(1):87-90

Pahnke K, Sachs JP, Keigwin L, Timmermann A, Xie SP (2007) Eastern tropical pacific hydrologic changes during the past 27,000 years from D/H ratios in alkenones. Paleoceanography 22(Pa4214):3. doi:10.1029/2007pa001468

Partin JW, Adkins JF, Fernadez DP (2007) Millennial-scale trends in west Pacific warm pool hydrology since the last glacial maximum. Nature 449. doi:10.1038/nature06164
Philander SGH (1990) El-Niño, La Niña, and the southern oscillation. Academic press, London

Rayner NA, Parker DE, Horton EB, Folland CK, Alexander LV, Rowell DP, Kent EC, Kaplan A (2003) Global analyses of sea surface temperature, sea ice, and night marine air temperature since the late nineteenth century. J Geophys Res 108(D14). doi: 10.1029/2002JD002670

Riedinger MA, Steinitz-Kannan M, Last WM, Brenner M (2002) A $610014 \mathrm{C}$ yr record of El Niño activity from the Galapagos Islands. J Paleolimnol 27:1-7

Rodbell DT (1999) An similar to 15,000-year record of El Nino-driven alluviation in southwestern Ecuador. Science 283(5410):2107

Rodgers KB, Friederichs P, Latif M (2004) Tropical Pacific decadal variability and its relation to decadal modulations of ENSO. J Clim 17(19):3761-3774

Sandweiss DH, Richardson JB, Reitz EJ, Rollins HB, Maasch KA (1996) Geoarchaeological evidence from Peru for a 5000 years BP onset of El Nino. Science 273(5281):1531-1533

Shulmeister J, Lees BG (1995) Pollen evidence from tropical Australia for the onset of an Enso-dominated climate at $\mathrm{C}$ 4000 BP. Holocene 5(1):10-18

Stott L, Cannariato CP, Thunell R, Haug GH, Koutavas A, Lund S (2004) Decline of surface temperature and salinity in the western tropical Pacific Ocean in the Holocene epoch. Nature 431:56-59

Swingedouw D, Braconnot P, Marti O (2006) Sensitivity of the Atlantic meridional overturning circulation to the melting from northern glaciers in climate change experiments. Geophys Res Lett 33(7)

Swingedouw D, Mignot J, Braconnot P, Mosquet E, Kageyama M, Alkama R (2009) Impact of freshwater release in the north Atlantic under different climate conditions in an OAGCM. J Clim 22(23):6377-6403. doi:10.1175/2009jcli3028.1

Timmermann A, Lorenz SJ, An SI, Clement A, Xie SP (2007a) The effect of orbital forcing on the mean climate and variability of the tropical Pacific. J Clim 20(16):4147-4159. doi:10.1175/ Jcli4240.1

Timmermann A, Okumura Y, An SI, Clement A, Dong B, Guilyardi E, Hu A, Jungclaus JH, Renold M, Stocker TF, Stouffer RJ, Sutton R, Xie SP, Yin J (2007b) The influence of a weakening of the Atlantic meridional overturning circulation on ENSO. J Clim 20(19):4899-4919. doi:10.1175/Jcli4283.1

Tudhope AW, Chilcott CP, McCulloch MT, Cook ER, Chappell J, Ellam RM, Lea DW, Lough JM, Shimmield GB (2001) Variability in the El Nino-southern oscillation through a glacial-interglacial cycle. Science 291(5508):1511-1517

Turney CSM, Kershaw AP, Clemens SC, Branch N, Moss PT, Fifield LK (2004) Millennial and orbital variations of El Nino/southern oscillation and high-latitude climate in the last glacial period. Nature 428(6980):306-310

Xie SP, Okumura Y, Miyama T, Timmermann A (2008) Influences of Atlantic climate change on the tropical Pacific via the Central American Isthmus. J Clim 21(15):3914-3928. doi:10.1175/ 2008jcli2231.1

Zhao Y, Braconnot P, Harrison SP, Yiou P, Marti O (2007) Simulated changes in the relationship between tropical ocean temperatures and the western African monsoon during the mid-Holocene. Clim Dyn 28(5):533-551

Zheng W, Braconnot P, Guilyardi E, Merkel U, Yu Y (2008) ENSO at $6 \mathrm{ka}$ and $21 \mathrm{ka}$ from ocean-atmosphere coupled model simulations. Clim Dyn 30(7-8):745-762 